The Challenges Faced by Reporting Entities on Their Transition to IFRS -

\title{
A Qualitative Study
}

Journal: Accounting in Europe

Lisa Weaver*a

Margaret Woods ${ }^{\mathrm{a}}$

${ }^{a}$ Aston Business School, Aston University, Aston Triangle, Birmingham, B4 7ET, UK

* Corresponding author. Email: 1.weaver@ aston.ac.uk 


\begin{abstract}
This study explores the challenges of implementing International Financial Reporting Standards (IFRS) at the organisational level. Based on interviews with experts with aggregated experience relating to the transition projects of over 170 reporting entities, this paper highlights the main challenges in delivering a successful implementation of IFRS. The findings show that the problems faced in implementation include lack of education and training, securing executive level support, identifying and responding to the wider business-related implications of the transition, and issues with capturing the necessary information for reporting under IFRS.

This paper complements the existing literature and offers a qualitative alternative to considering the transition to IFRS, offering insight into the organisational context of IFRS implementation. These insights are useful not only from a historic perspective, but also for organisations and regulators in the many jurisdictions where IFRS is permitted but not required, where more reporting entities will voluntarily move to IFRS based reporting in the future. More broadly, they are also applicable to the challenges faced in implementing new and significantly revised IFRSs.
\end{abstract}

Key words: IFRS transition, implementation, challenge, consultant, implications 


\section{Introduction}

The process of global harmonisation of financial reporting standards has been rapid over the last decade, and many thousands of reporting entities have moved from following jurisdiction-specific standards to international standards, namely International Financial Reporting Standards (IFRS). The objective of this paper is to identify and explore the organisational challenges faced by reporting entities in the transition to IFRS. It is hoped that the findings will offer insights useful to regulators, professional firms and reporting entities.

There is a plethora of quantitative research on the post-adoption implications of IFRS on financial reporting matters such as reported equity and earnings, disclosures, transparency and accounting quality. In addition, much has been published on the perceived benefits for organisations that use globally accepted financial reporting standards. Reduced cost of capital, increased access to sources of finance, better comparability of financial statements and higher quality financial reporting are all cited as reasons for supporting the harmonisation of accounting practice (Walton, 2009, p. 15).

To date, little academic research has been published on the process of transition itself and the challenges it poses for reporting entities. Survey based research that examined how 112 publicly traded companies prepared for transition to IFRS in the EU in 2005 found it to be a costly, complex and burdensome process (Jermakowicz \& Gornik-Tomaszewski, 2006). The study did not, however, analyse the challenges at the individual organisational level. Using a case study method, Lantto studied the implications of IFRS adoption for the work of the management accountant in a business but her focus was on changing accounting roles rather than the wider discussion of challenges caused by transition (Lantto, 2014). We would therefore suggest that there remains a gap in knowledge and understanding of how individual companies manage the operational challenges of IFRS transition, and it is this gap that our paper seeks to directly address.

This paper complements the existing literature by using a qualitative research approach to explore the organisational experiences of transition, and the potential lessons to be learned. The dataset is international, covering the UK, EU, Canada and Australia, and referencing the knowledge of people directly involved in over 170 transition projects. We focus on the problems faced during transition, including staff training, access to resources, and the wider impact of the transition on non-accounting business functions, as well as the significance of the 'tone at the top'. Whilst all of these issues were mentioned by Jermakowicz and Gornik-Tomaszewski (2006) and Lantto (2014), we discuss them in more depth and provide illustrative examples.

We believe that the findings will be useful not only to reporting entities in the small number of jurisdictions, such as Vietnam and Japan, which are yet to fully adopt IFRS-based financial reporting, but also those where IFRS is permitted but voluntary, and growth in the use of IFRS is anticipated. In such jurisdictions there are likely to be considerable challenges to IFRS implementation due to the differences between national accounting standards and IFRS, as well as significant cultural issues. The findings are also relevant to reporting entities 
already using IFRS but faced with the challenges of implementing significant new or revised IFRS requirements. We find that whilst the accounting implications and impact of IFRS on reported profit and financial position commonly capture the headlines, the biggest implementation challenges usually relate to matters such as securing executive support and resources, and issues such as lack of education, training and familiarity with IFRS principles and requirements. The wider implications for business processes of the adoption of IFRS are also significant. It is these 'behind the scenes' issues which cause transitions to be problematic, rather than the complexities of applying new accounting rules.

Our findings also suggest that the organisational context of transition to IFRS is under-researched, and there are many cross-disciplinary topics that would benefit from further study. Examples include the use of project management techniques in planning the transition, the role of organisational psychology in shaping the efficiency and perceived success of a transition, and the significance of a strong corporate governance support mechanism for those involved in the transition. Our findings also indicate that external auditor's objectivity is threatened where a reporting entity relies heavily on the input of the auditor as an advisor during the period of transition.

The paper is structured as follows. The next section provides a brief background on the global harmonisation of financial reporting standards and this is followed by a review of existing research on the impact of transition to IFRS. Research methodology is then discussed and the findings presented. This section summarises the specific and significant challenges faced in planning and conducting a transition. We conclude that senior management in entities tends to adopt a compliance focus to the transition to IFRS, whilst paying limited attention to the underlying business implications, training and resource requirements. There is also a need for further research to improve our understanding of the process at the entity level.

\section{Background}

IFRSs are issued by the International Accounting Standards Board (IASB), and it is up to individual jurisdictions to decide whether to adopt them. The aim of the IASB is to develop a single set of high quality, understandable, enforceable and globally accepted financial reporting standards based upon clearly articulated principles (IFRS Foundation, 2014a).

Hans Hoogervorst, the IASB Chair, has stated that there is almost universal support for IFRS as the single set of globally accepted accounting standards (Hoogervorst, 2013). The transition to IFRS has gathered pace in the last decade, and financial reporting based on IFRS is now the norm for publically accountable reporting entities around the world. In charting progress towards the global adoption of IFRS, the IFRS Foundation found that of 140 jurisdictions surveyed, 116 jurisdictions require the use of IFRS for all or most domestic publicly accountable entities (listed companies and financial institutions) and most of the remaining 24 jurisdictions permit IFRS use for some reporting entities (Pactor, 2015). 
The EU decision to require listed reporting entities to adopt IFRS from 2005 was momentous. At this time approximately 8,000 reporting entities implemented IFRS (Zeff, 2012) despite considerable implementation challenges arising from the lack of experience amongst both preparers and their advisors of IFRS-based financial reporting.

The move to follow IFRS in EU member states spurred other countries to adopt a similar regulation. A second tranche of countries then moved to follow IFRS, while some countries retain their own national accounting standards, realigned with IFRS and so converge with, rather than adopt, IFRS. The IASB recognises that convergence is a powerful driving force in the adoption of globally accepted financial reporting standards, stating in a 2012 Strategy Report that 'convergence may be an appropriate short-term strategy for a particular jurisdiction and may facilitate adoption over a transitional period.' (Pactor, 2014). Reporting entities implementing national standards that are converged with IFRS face similar transitional challenges to those adopting IFRS as issued by the IASB.

Much of the work of the IASB since its formation has been focussed on convergence with US Generally Accepted Accounting Practice (US GAAP). While the appetite for IFRS implementation in the US is still being debated, it is likely that more reporting entities in the US, especially those with cross-border listings may on an individual basis choose to implement internal IFRS reporting to a greater or lesser degree. The Institute of Chartered Accountants in England and Wales (ICAEW) comments that 'It is likely that the US Securities \& Exchange Commission (SEC) in time will conclude that IFRS is suitable for use also in the US and on that basis will begin moving towards allowing greater use of IFRS or incorporating IFRSs into US GAAP' (ICAEW, 2014b). Implementation challenges are likely to become highly significant should the SEC more closely align US GAAP with IFRS and under such circumstances, our findings would be relevant to all affected US reporting entities.

Similar challenges will be faced by reporting entities in other jurisdictions moving towards IFRS-based financial reporting. For example, in the UK new Financial Reporting Standards, largely based on IFRS principles and requirements, become effective in 2015 for companies that are currently not required to use IFRS (Financial Reporting Council, 2014).

Certainly for those involved with the first wave of transition in the EU, there was little experience of IFRS, and a short amount of time to plan for and execute the transition. Consequently, preparers of financial statements relied heavily on external help to manage the transition. The IASB does not offer guidance on how to manage a transition to IFRS; such guidance may instead be published by the relevant regulatory authority. For example, in the EU, the Committee of European Securities Regulators (CESR) advised companies on a range of matters including the presentation of the first IFRS financial statements and the communication of transition-related matters (CESR, 2003). However, the regulatory authorities provide little guidance on the implementation strategy that a reporting entity should adopt, and it is the authors' experience that reporting entities turn to their external auditors or other IFRS consultants for help in planning their transition, and identifying and mitigating the associated problems. 
In practice it is the accounting firms that provide the most implementation guidance (for example Deloitte, 2009; Grant Thornton, 2012; KPMG, 2009; PwC, 2007, 2009), much of which was first published during the EU transition to IFRS and has subsequently been developed and enhanced. In 2005/6 there was very little other published guidance available and even the accounting firms themselves had little experience of IFRS or the challenges of its implementation. For later adopters, for example in Canada which moved to adopt IFRS in 2011, preparers of IFRS financial statements were able to benefit from the experience of those that had already gone through the transition, which, in principle, should have made implementation an easier process. Our evidence, however, suggests that many challenges are common to both early and late adopters.

\section{Literature Review}

The move to IFRS created huge research opportunities. The published research on IFRS can usefully be categorised under three core themes, namely, the impact of IFRSs on value relevance, accounting quality and disclosure; on financial statements and ratios; and on the costs and benefits of transition. As already noted, research on the organisational context of IFRS implementation is limited. There are many papers analysing the quality of accounting information in particular countries after the implementation of IFRS. Some studies look in particular at earnings management (for example Aubert \& Grudnitski, 2012; Cordazzo, 2013), and others focus on value relevance (for example Filip \& Raffournier, 2013; Tsoligkas \& Tsalavoutas, 2011).

At the organisational level, most of the research to date has focused on the impact of IFRS on the cost of capital. One of the suggested benefits of the harmonisation of financial reporting standards is that the cost of capital should reduce (Daske, 2006; Kim, Shi, \& Zhou, 2014). Other studies suggest that companies may also expect non capital related benefits from migration to IFRS, such as reduced costs and risks from overseas operations (Etnyre \& Singhal, 2011), or more effective contracting with customers and suppliers (Hail, Leuz, \& Wysocki, 2010).

The costs of transition have been subject to a limited number of studies, which often focus on audit fees (for example De George, Ferguson, \& Spear, 2013; Redmayne \& Laswad, 2013). One EU-based study found that the average audit fee increase was $5.44 \%$ greater for IFRS adopter firms compared with non-IFRS adopters over the period 2004 - 2008 (Kim, Liu, \& Zheng, 2012, p. 2077). These findings are supported by a Canadian study which revealed, perhaps unsurprisingly, that the costs of transition vary proportionately with the size of the reporting entity and the complexity of the transition (CFERF, 2013). The on-going cost implications of IFRS implementation for individual businesses are, however, rather less well understood and attention has largely been focused on the one-off costs of transition. According to the ICAEW, looking at the EU specifically 'there appears to be no academic research on recurring preparation costs, other than Kim et al (2012) which finds higher audit costs' (ICAEW, 2014a, p. 127) Such on-going costs are likely to be substantial, as spending is required on systems modifications and external consultant's fees, as well as the incremental costs of dual reporting (Naoum, Sykianakis, \& Tzovas, 2011). These studies are very useful 
in highlighting the costs of transition to reporting entities, however there is little research on whether sourcing finance for transition is a significant challenge, or whether cost is perceived to be a major impediment in executing the transition.

In exploring the process of transition to IFRS, one study used interviews to capture the thoughts of a sample of auditors, preparers, regulators and users in the UK, Ireland and Italy (ICAS, 2008). The study concluded that 'overall the implementation of IFRS has not been an easy process. Although the financial impact has often been negligible, the changes within organisations to their systems and processes should not be under-estimated'. It is clear, however, that a key issue remaining under-researched within the literature is that of how organisations respond to the challenge of implementing IFRS. Lantto (2014) argues that 'there is little, if any, empirical evidence as to whether - and if yes how - IFRS adoption will change reporting practices and what implications IFRS adoption will have on an organisational level in a continental European context', and that '[the] actual preparation of reporting information (i.e. practices and mechanisms used) has received little attention' (Lantto, 2014, p. 336).

The research findings outlined above offer insights into how the implementation of IFRS has a direct impact on equity, asset valuation and income measurement, as well the understandability, transparency and comparability of reported financial information. The literature thus extends the debate on whether or not IFRS improves financial reporting and reduces the scope for manipulation of financial information. The bulk of academic research on IFRS to date has, however, utilised quantitative rather than qualitative research methods and our understanding of how individual entities meet the challenges of implementation is therefore limited. A survey based study of IFRS implementation challenges published by Jermakowicz and Gornik-Tomaszewski, (2006) and shown in Table 1, provides the grounding for our research.

\section{INSERT TABLE 1 HERE}

The challenges listed in Table 1 emerged from a 2004 survey of EU listed companies, and so the data collected was concurrent with the first major phase of transition within the EU. The authors discussed the issue of accounting complexity under IFRS as a major challenge, but, perhaps because the data was collected via a survey, there was minimal discussion of other issues such as lack of implementation guidance, the scope for interpretation within IFRS, and staff knowledge and training in respect of IFRS. Our paper builds on the survey work of Jermakowicz and Gornik-Tomaszewski (2006) by using case study evidence to explore in greater depth the implementation challenges identified in their survey. In addressing a wide range of transition challenges, our case study evidence also complements the work of Lantto (2014), and we hope it marks a shift towards more innovative and qualitative research in this field.

\section{Research Method}

This paper uses qualitative research to capture the perceptions of a range of qualified professional accountants on the challenges faced by preparers in transitioning to IFRS based 
reporting. Semi-structured interviews were conducted with individuals, all of whom have been, and many are still, directly involved in the transition of both private sector and public sector reporting entities to IFRS. All of the individuals included in our sample are members of recognised professional bodies.

Anonymised details on the 14 respondents are provided in Appendix 1. Our sample includes six auditors and eight consultants. The auditors all worked for professional services firms as managers responsible for the external audit of reporting entities implementing IFRS. Two auditors worked at "Big 4" firms, and four at "Mid-tier" firms. The consultants were not employees of a professional services firm at the time they consulted on IFRS implementation but had all worked at professional services firms in the past. Several individuals had a wide range of IFRS implementation experiences with a large number of different reporting entities. For example, one consultant had been engaged to provide advice on over 50 transition projects for a range of reporting entities including groups with cross-border listings, financial institutions, public benefit entities, private companies, pension plans and charities. As indicated in Appendix 1, all of the respondents have many years of experience working on IFRS transitions, and several of the UK-based respondents had experience of transitions dating back to 2005 .

The nature of the involvement of the respondents varied between the projects. It is therefore difficult to generalise about the type of activities/work that they performed, other than they all provided accounting advice. The consultant responders were IFRS experts and provided technical accounting advice to their clients, particularly on the application of IFRS 1 First-time Adoption of IFRS. The auditor responders also provided advice, with the depth of their involvement varying client by client. A comment from Respondent 7, a consultant to Canadian companies, clearly illustrates this:

"My inputs to clients' IFRS transitions ranged from what I would call 'full immersion' to simply checking compliance with the IFRS standards. Full immersion would be pretty much taking control of the process and managing it for the client. I would make a lot of the decisions on the accounting that was needed. At the other end of the spectrum I would just check the IFRS 1 adjustments and review the reconciliations produced between Canadian GAAP and IFRS."

The respondents were selected on the basis that their wide ranging experience would provide rich case study data and illustrations covering a variety of corporate structures, industry sectors and geographical locations, focusing on the EU but including other geographical areas with different dates of transition. Several Canadian interviewees were included in the sample to allow us to examine whether the later adoption of IFRS in Canada compared with the EU reduced or changed the challenges of implementation, as lessons from the EU were applied to Canada

Contact with potential respondents was made in several ways. Most were contacted at conferences and events held by regulatory and professional bodies, others were introduced to the authors through professional contacts. We acknowledge that a larger number of 
respondents would have provided a richer source of information and that the small sample is a limitation of our findings. Nonetheless, the respondents' views when aggregated represent involvement with over 170 transition projects thus providing a wealth of experiences on which to reflect and comment.

The difficulty of obtaining access to potential respondents for the purpose of conducting qualitative research is widely recognised. A reluctance to agree to interview may be explained by lack of interest in the subject matter, lack of time and them seeing no personal benefit in providing an interview. Literature on conducting interview-based research suggests that 'business is comparatively more likely to be wary of, or else indifferent towards, encounters with academics' (Welch, Marschan-Piekkari, Penttinen, \& Tahvanainen, 2002). Our research experience echoes these findings. Over 50 potential interviewees were contacted, and only 14 proved amenable to interview, with most of those who declined quoting constraints on their time as the reason for non-participation.

The willingness of respondents to participate in the study therefore drove our sample selection and also impacted on the geographical diversity of the respondents. Potential respondents were contacted in a wide variety of countries including India, Brazil, France and Italy but none of these agreed to be interviewed - sometimes citing a lack of financial incentive to take part as a reason. We acknowledge that there is therefore an Anglo-Saxon bias in our selection and encourage further studies to extend geographical coverage of this research topic. We also acknowledge that there is an element of self-selection in our sample of interviewees and that other implementation challenges may have become evident in our findings had our sources of information been from a wider pool of respondents with less Anglo-Saxon bias.

The data was collected in 2013 within a three month period to reduce the risk of temporal bias. Responses took three different forms: seven face-to-face interviews, two skype interviews, and in the remaining five cases, where it proved too problematic to arrange a face-to-face interview or skype call, the respondent provided written feedback on the thought-provoker questions (illustrative examples are included in Appendix 2). The face-toface and skype interviews lasted on average for 70 minutes.

The arguments in favour of face-to-face interviewing include that more accurate responses may be received owing to contextual naturalness, there is a greater likelihood of self-generated answers, and that it is more effective for complex issues (Shuy, 2002). Using skype as an interview tool in qualitative research is a growing phenomenon and is increasingly recognised as a useful way to interview research participants especially where interviewees are geographically dispersed (Deakin \& Wakefield, 2014). We acknowledge that it would have been preferable to collect all responses by interview, particularly because we could not use content mining-techniques for the written responses. However, the written responses were extremely useful in that they contained well explained answers and detailed case studies as examples - possibly the interviewees had time to reflect in more detail than in the face-to-face or skype situations. 
The interviews were not tape-recorded, but instead detailed notes were taken by the interviewer. The decision not to tape-record was mainly influenced by a desire for the interviewees to speak freely and discuss matters relating to their clients. This research method follows the argument of Stoner and Holland (2004, p 44), that 'the potential loss in research vigour and validity are acceptable in order to obtain data that would not be possible were we to adhere to the purer forms of phenomenological interview research'. The nature of the relationship between the auditor / consultant and their client calls for confidentiality to be observed. All the interviewees were therefore assured that their comments would remain anonymous and that the names of any reporting entities would remain confidential. The candid nature of some of the discussions that took place in interviews indicated that a relationship of trust had developed and that the interviewee was happy to provide frank comments, often highly critical of the actions of the reporting entities whose transitions they had been involved in. The short interview and response extracts that are included in this paper have been modified where necessary to preserve this anonymity and confidentiality.

The interviews enabled us to obtain personal accounts of the transition of IFRS, and an interview technique based on content mapping and content mining was used to allow the research agenda to be opened up. Content mining questions are 'widely framed questions designed to encourage spontaneity and to allow the interviewee to raise the issues that are most relevant to them' (Legard, Keegan, \& Ward, 2003, p. 148). Care was taken not to ask leading questions, and to phrase the questions more indirectly as thought-provokers, for example: 'What challenges have you experienced when working on a transition to IFRS?' Once main themes had been established, content mining questions were used to probe the issue in more detail. For example where the interviewee had raised a lack of resources as a challenge, they were asked if they could elaborate on the type of resource and to explain why it was an issue. The semi-structured approach allows the interviewee to express their thoughts more freely and facilitates more detailed discussion of the topics that they deem more important. The authors took care to eliminate the potential impact of personal preconceptions on the interview process, and ensure that the data collected could be 'relied on to raise the research issues and to generate novel case data independent of the researcher's prior views' (Stoner \& Holland, 2004, p. 41).

The interview notes were transcribed and the written responses were read to ascertain the common opinions and perceptions expressed by the interviewees, using a qualitative thematic analysis framework. This framework is 'used to classify and organise data according to key themes, concepts and emergent categories' (Ritchie, Spencer, \& O'Connor, 2003) and allows the themes to be identified, categorised and indexed to determine the prevalence of each identified theme. The themes were ordered into a hierarchy according to three separate criteria: the number of interviewees that had discussed that theme, the number of times each respondent had raised the theme and the level of importance attached to the theme by the interviewee. We acknowledge that there is an element of subjectivity in this analysis, but nonetheless a prioritisation of themes is evident from the information obtained from our respondents. 
Relevant literature indicates that generalisation may be achievable at the level of concepts and themes, but that it is unlikely that the results from most qualitative research can be extrapolated or could be replicated (Schofield, 2002). In respect of this study, the experience of each reporting entity's transition to IFRS is different, as well as the involvement of the interviewee with that transition. Nonetheless, the evidence presented below does suggest that a number of common challenges can be identified and these themes are useful for informing further research.

\section{Findings: The Key Entity Level Challenges of Implementing IFRS}

The core themes [or challenges] that emerged are lack of education on IFRS often leading to issues with 'copying' the actions of other reporting entities, problems caused by lack of management support, the implications of adopting IFRS on the wider business, and difficulties in accessing the necessary information for the first IFRS-financial statements. Our findings are discussed in the order of importance attached to them and the tables below summarise the results of the thematic analysis.

\section{Insert Table 2 here}

Table 2 shows the number of times that each theme was discussed by each individual, and where an issue was highlighted as "key issue" or "priority" by the individual this is denoted. The respondent would often state when something was "the key issue" but importance was also gauged by the tone and nature of the comments made.

Table 2 shows that lack of knowledge and experience of IFRS was the only issue discussed by all of our respondents. Seven of the respondents raised this issue more than once and five prioritised this as a key challenge in IFRS implementation. Difficulties in developing accounting policies was the next most important challenge, discussed by 11 of our respondents and prioritised by four of them. These two challenges are linked, as presumably the lack of knowledge and experience of IFRS makes it difficult to develop IFRS-compliant accounting policies. Lack of management support and failure to anticipate the wider business implications were raised as issues on 13 and 12 occasions respectively, and prioritised by four and two respondents respectively. Difficulty in capturing data was raised as a challenge six times by five respondents, with three respondents prioritising it as a significant issue.

Five other issues were raised, but none of these were categorised by any respondent as a significant issue. These issues were systems / IT capacity, lack of upfront planning, costs and fees, implementing specific IFRS requirements, and over-reliance on specialists.

\section{Insert Table 3 here}

Table 3 presents a summary of the thematic analysis with the challenges ranked according to a combination of the number of times the issue was raised by the respondents and the number of times the issue was prioritised. 
As noted above, it is interesting that while some of the interviewees mentioned the challenges of applying specific IFRS requirements, this certainly did not emerge as a key implementation challenge. This was somewhat surprising, given the extent of the literature that comments on the relative complexity of IFRS financial reporting and disclosure requirements. Overall, the challenges identified by respondents show similarities with those found by Jermakowicz and Gornik-Tomaszewski (2006) as illustrated in Table 1, but our work adds to theirs by both identifying the issues that were prioritised and adding new challenges that they did not identify e.g. difficulties in capturing data and lack of management support. A more detailed comparison of our findings with those of Jermakowicz and Gornik-Tomaszewski, (2006) is contained in the next section of this paper but we first look at each specific challenge in greater depth.

\subsection{Lack of Knowledge and Experience with IFRS}

There is evidence from existing literature that education and knowledge was an issue for those involved with the EU-adoption of IFRS in 2005. For example Hoogendoorn observed that that many entities lacked the necessary expertise to implement IFRS and were consequently heavily reliant on their auditors for advice (Hoogendoorn, 2006). This view was confirmed by Jermakowicz and Gornik-Tomaszewski (2006), who identified education and training as a key challenge. At the time, very few accountants had practical experience of IFRS-reporting, and professional examination syllabi did not include IFRS. However our evidence suggests that the issue was deeper-rooted than simply having little knowledge of specific IFRS requirements.

For many accountants the move to IFRS involved a change in accounting mind-set, as IFRS is built on a different framework to some national GAAPs. In such situations, the transition to IFRS proved extremely challenging, not only because the preparers of financial statements had little knowledge, but because they had to develop new skills, particularly in the use of judgment in making accounting decisions. It is well documented that IFRS is a relatively principle-based financial reporting framework (for example Bennett, Bradbury, \& Prangnell, 2006; Wüstemann \& Wüstemann, 2010). Consequently, moving from a more rulebased framework, as followed by many continental European reporting entities, proved very difficult and necessitated not only education on the principles and requirements of IFRS but also a different approach to accounting. The comment of Respondent 11, working on German company transitions to IFRS illustrates this well:

'Here in Germany a major problem has been the different way of thinking [under IFRS] - on the one hand a law-guided accounting system, on the other a system based on professional judgment. It is absolutely uncommon for a German accountant to decide - he / she needs rules to follow and, in general, he / she will not deviate. As an example, when explaining to a German accountant used to applying rule-based German GAAP the necessity for certain items to be measured at fair value under IFRS, he stated that he would not be involved in such an "incredible accounting fraud". It was very difficult to persuade accountants of the validity of IFRS requirements.' 
These findings support the observation made by Carmona and Trombetta (2008) that the implementation of the principles-based approach in IFRS brings about a number of fundamental changes in the backgrounds and skills of accountants and auditors. They further comment that the transition from rules based to principles based accounting that accompanies a move to IFRS is challenging to those accountants trained in certain continental Europe traditions (Carmona \& Trombetta, 2008). Lantto (2014) found similar evidence in her Finnish case study company, where accountants described as 'black spots' the instances where personal interpretation was required. The evidence confirms Hoogendoorn's (2006, p.24) observation that 'there is an area of tension between a principles-based interpretation of IFRS and a rules-based interpretation'.

The challenge of changing accounting traditions is not, however, just confined to the principles versus rules arena that is highlighted within the private sector. For many public sector entities, the move to IFRS is much more of a shift in the financial reporting framework than for private sector firms and this was reflected in limited access to skilled staff. Respondent 9, who advised on many public sector reporting entity transitions highlights this point:

'With the major change from cash to accruals accounting there was a clear need to have access to staff with good technical knowledge and understanding of the concepts and requirements as set out in the changed reporting requirements. This proved difficult in the public sector as few staff had accounting qualifications and even those that did had very little practical experience with the development of accounting policies, estimates and subsequent disclosures'.

These comments confirm the findings of Jermakowicz and Gornik-Tomaszewski (2006, p.192) who state that 'a lack of adequate education, training, and knowledge of IFRS are important challenges of conversion' and 'a training program for staff across a company is needed to let them adopt an entirely different system of business operations, performance measurement, and communication with the markets.' Our respondents indicated that this should happen at the start of transition planning, and that the need for education should not be under-estimated. There is some evidence that training costs can amount to a significant proportion of transition costs. For example in a study of Greek companies that moved to IFRS, over one third of finance directors stated that personnel training costs were the most onerous of the costs incurred in their transition projects (Ionaşcu, Ionaşcu, Olimid, \& Calu, 2007). Little research has been conducted, however, on the type of training required, such as the need to focus on the framework-based nature of IFRS and the development of skills in exercising professional judgment.

It also became clear from the respondents' comments that reporting entities would often provide training to a few key individuals only, usually due to time constraints or lack of funding. Respondent 8 expressed an opinion on this issue:

'Another impact from the general lack of knowledge and experience was that those who had some training and knowledge of IFRS were perceived as "experts". Unfortunately this meant 
that some concepts were promoted as "the way it needs to be done" which was based on poor understanding of the requirements. These later needed to be corrected and resulted in delays and wasted resources.'

In cases where the breadth of IFRS knowledge is relatively thin, there is not just the risk of potential errors in interpretation, as suggested in the quote above, but also a possible threat that the IFRS language fails to permeate the wider business. Lantto (2014) notes the benefits of thinking and talking the IFRS language even amongst divisional accountants.

A number of respondents observed that the lack of in-house experience with IFRS meant that at times a heavy reliance was placed on the external audit firm to provide assistance. However, auditors also often faced a knowledge gap. Hoogendoorn (2006, p.25), based on his own experience as an auditor, comments that 'IFRS is too complex, even for auditors and other specialists'. Auditors had limited exposure to IFRS at the time of many transitions, so when called upon to offer guidance and advice to their clients, problems arose. Many interviewees spoke of audit firms being only 'a small step ahead' of their clients in terms of technical knowledge of IFRS. Respondent 9 commented:

"Unfortunately the level of [IFRS] technical knowledge in audit at the time was quite low and resulted in the widespread adoption of practices which in retrospect should never have been allowed. However once adopted it has been difficult to wind back poor practices that have been embedded by audit not wishing to highlight their previous mistakes so have continued to accept poor practices."

An interesting feature of the discussions on auditor competence regarding IFRS can be seen in the comments made by two of our Canadian respondents, who both raised the issue of Canadian audit firms' lack of experience with applying IFRS. Respondent 12 comments that 'not all auditors were well trained on IFRS'. Respondent 7, also a Canadian consultant, commented that she was mainly engaged by companies to obtain expert advice on IFRS due to the audit firms lacking experience in the application of IFRS 1 First-time Adoption of IFRS. Respondent 7 stated that errors were often found in the IFRS 1 adjustments suggested to the company by their external audit provider and describes the following situation as 'not uncommon':

'In most of the transitions I dealt with I acted as a kind of middle-man between the company adopting IFRS and its auditor. I often checked over the transitional adjustments that had been suggested by the audit firm and found mistakes. Sometimes these were not significant, but in some cases they were. I had to question the ability of the audit firm and their knowledge of IFRS. Also I looked over the notes to the accounts and found items missingthere was definitely an issue of completeness. The auditors had missed disclosures but the accounts had a clean audit report. This issue was across the board, not just small audit firms but the big ones too.'

The comments made by these two Canadian respondents indicate that despite the Canadian transition being six years later than that of the EU and Australia, audit firms in Canada did not appear to have built up a knowledge or experience of IFRS. Up until the point 
of transition, Canadian companies and their auditors focused on national accounting standards and it seems that there was limited up-front training on IFRS prior to its implementation. This confirms earlier research on the level of preparedness of reporting entities moving to adopt IFRS. A study on IFRS implementation in the Czech Republic conducted interviews at nine companies and found that even close to the date of transition, an attitude of 'wait and see' prevailed, and many smaller companies had not taken any action over preparing IFRS financial statements (Sucher \& Jindrichovska, 2004).

At the time of Canadian transition, the global accounting firms clearly had experience of IFRS in other jurisdictions but possibly this knowledge was not well disseminated across national boundaries. The audit firms had named 'IFRS experts' but it would appear that IFRS knowledge was concentrated with those experts, and members of audit teams, especially more junior members, may not have had the necessary knowledge of IFRS at the time of the client's transition.

Dependence on, and use of external experts to help with the transition process was noted by Jermakowicz and Gornik-Tomaszewsk (2006, p.192), who suggested that audit firms 'play the crucial role' in the training programmes put in place by companies implementing IFRS for the first time. Their survey responses revealed that $73 \%$ of the firsttime adopters had, or planned to use external expertise during the conversion project. Of those opting to use external expertise, 57\% employed their current external auditor in this capacity, whilst the remaining respondents used a different external expert. Lantto (2014) in her Finnish case study similarly found that the accountants at the case firm emphasised the importance of help from IFRS consultants and their European networks, especially in the initial planning stages of the transition.

These comments say more about the challenges faced by the audit firms than by the reporting entities on the transition to IFRS, and serve to highlight the breadth of the issue. They also confirm that lack of knowledge can be a significant barrier to the successful adoption of IFRS. If reporting entities indeed make mistakes in their financial statements that subsequently needed to be rectified, the impact on corporate image and the trustworthiness of the reported information could create problems in post-adoption periods. This also raises an important issue on the quality of financial reporting post-IFRS implementation. Just because a country and its reporting entities adopts IFRS it does not mean that the right choices are being made in terms of the interpretation and application of IFRS requirements, especially in respect of the more judgmental areas and in relation to disclosure in the notes to the financial statements.

A further issue highlighted by our findings relates to the issue of auditor objectivity. Regulatory bodies mandate that auditors must be able to demonstrate their independence from their audit clients. A particular threat to independence raised by audit firms becoming heavily involved with the transition to IFRS is that they participate in making management decisions regarding the preparation of the financial statements. A self-review threat is also created whereby the audit firm is less likely to be critical of accounting treatments contained in the financial statements that they themselves have helped to prepare. For these reasons, 
there is a general prohibition on external audit firms from becoming involved in the preparation of their clients' financial statements. It is therefore interesting that our findings indicate that in some cases the audit firm may have overstepped the line and provided accounting services that would be perceived to threaten their objectivity.

The Code of Ethics issued by The International Ethics Standards Board for Accountants (IESBA) states that 'the client may request technical advice on accounting issues such as the conversion of existing financial statements from one financial reporting framework to another (for example, transition to a different financial reporting framework such as IFRS). Such services do not, generally, create threats to independence provided the firm does not assume a management responsibility for the client' (IESBA, 2015, p.74). Only three of our respondents discussed auditor independence issues, and even then it was not discussed as a 'challenge'. This suggests that both preparers and auditors of financial statements accepted that the external auditor would be likely to have heavy involvement in the transition to IFRS and did not see this as a problem. For regulatory and professional bodies, however, this potential lack of auditor objectivity could be an issue, and would seem to be an area worthy of further research.

\subsection{Difficulties in developing accounting policies}

It was clear from comments made by respondents who had been involved with EU early-adopters of IFRS that it was very difficult for the reporting accountants to develop accounting policies, mainly due to their lack of knowledge of IFRS and inexperience in applying judgment on appropriate accounting treatments. Many of the interviewees spoke of how reporting entities would look to their peers when establishing IFRS-compliant accounting policies. There is of course good reason for this - companies want their financial statements to appear consistent with those of their competitors especially when faced with developing accounting policies based on an unfamiliar framework. In addition, the accounting firms issued template financial statements which served to promote consistency in the appearance of published financial information. The preparers of the first IFRS financial statements of a reporting entity would effectively 'copy' the presentation from the templates provided by auditors. The auditors themselves would look to previous published IFRScompliant financial statements for 'inspiration' and guidance on the appropriate level of disclosure provided in the notes.

Respondent 3 raised this point during our discussion:

'I worked on the audit of some of the earliest IFRS-adopters in the UK. We had no comparisons that we could make with UK companies to look for presentation and accounting treatments, so we looked to European companies. We quickly learned that even if we used the same accounting policy, the notes would need to be completely different and care must be taken to make the notes specific to the company and not just boilerplate.'

In some industries, the transition to IFRS fostered networking and an improved dialogue between companies operating in the same sector. Anxious to present a united message to stakeholders, it is common that working groups are established within an industry 
to discuss the impacts of transition, both accounting and business wide impacts, and to agree appropriate responses. A main objective of such groups is to consider the accounting policies that should be developed for industry specific transactions and balances. In the UK, the external audit firms often played a part in setting up these groups for their clients. Respondent 2 raised this issue, saying that:

'We [the audit firm] encouraged our clients to attend an industry meeting every quarter so they could discuss similar issues and talk about consistency. The audit firm would give options and the companies would choose - usually based on what others were doing. These working groups were very useful in developing accounting policies that became seen as the industry norm for our clients in a particular sector. There is improved dialogue and better communication between audit firm and client about accounting policies, this is an on-going benefit of the transition to IFRS.'

Thus, the preparers of the financial statements would respond to the challenge of having limited experience in applying IFRS by sharing experiences and taking the lead from their audit firms. This is likely to generate further consistency of accounting treatments within an industry, making financial statements more comparable. The role of the audit firm in helping to determine accounting policy is discussed by Touron, who suggests that 'within the business world, practices are adopted because they are prescribed by professionals' (Touron, 2005, p. 855). In the language of Lantto (2014), the auditors are experts who act as knowledge brokers within a community of practice. Respondent 4 commented that 'in the choice of accounting policies, the key issue [for the reporting entity] is what everyone else is doing. Perception is important, so companies look at their competitors'.

The fact that reporting entities rely on their auditors and peers for information and guidance when developing accounting policy may contribute to isomorphism, a concept by which reporting entities become increasingly similar and homogenised (DiMaggio \& Powell, 1983). The types of isomorphism that appear particularly relevant in the adoption of IFRS are coercive isomorphism, which arises from political and regulatory interference in the actions of reporting entities, and mimetic isomorphism, the mechanism by which reporting entities model themselves on other reporting entities, particularly in situations of uncertainty. From the comments made by the respondents it appears that mimetic isomorphism is a particularly powerful force when IFRS is adopted, as reporting entities benchmark themselves against each other, and appear to 'copy' the actions of their peers. This is a little researched area in the context of IFRS adoption but is very important in that IFRS is a financial reporting framework that should be tailored, to an extent, to the situation of the reporting entity in order to make the financial statements as relevant as possible to the users of the financial statements. Mimetic isomorphism, if found to be prevalent when a group of reporting entities move to IFRS, potentially undermines the qualitative characteristics of useful financial information as stated in the IASB's Conceptual Framework - namely relevance and faithful representation (IFRS Foundation, 2010). Our evidence suggests that in determining accounting treatments, the preparers of the financial statements base their decisions largely on the advice of the external auditor, and by comparisons to peers. The process is fueled by the preparers' lack of knowledge and familiarity with applying IFRS. 
Comments on the lack of experience with IFRS, based on the EU transition process, can offer valuable insight to those reporting entities yet to make the transition. It is an issue picked up by the US Securities and Exchange Commission, whose 2007 Concept Release comments that 'the education of most accountants in the United States - be it collegiate or continuing education -includes a comprehensive curriculum around U.S. GAAP but does not include a similar curriculum around IFRS. Most specialists, such as actuaries and valuation experts, who are engaged by management to assist in measuring certain assets and liabilities likely were not taught IFRS' (SEC, 2007, p. 29). Walton (2009, p.46) argues that early training is vital to ensure that companies can secure training for their staff, because trainers with an appropriate level of IFRS knowledge become a scarce resource.

\subsection{Lack of support and a resistance to change}

Amongst the respondents there was a strong feeling, often articulated in a manner highly critical of the reporting entities to which the comments relate, that the implementation of IFRS was not given the support it deserved by senior management. This was often coupled with comments suggesting that at executive level there was a resistance to the required changes, and that management while not deliberately undermining the work of the accountants in planning the transition project, provided little help or support. In essence, there was an inappropriate 'tone at the top' which indirectly hindered the transition project. Respondent 12 comments as follows:

'There was definitely in general a lack of commitment and understanding from the executive level. Despite the changes being mandated by legislation there were regular calls to return to the 'old days' before IFRS. There was a strong push to stick with what they had previously done. They saw the changes as creating more complexity and an increased workload. People tried to find short-cuts rather than doing it properly because of the increased workload and this was endorsed by senior management.'

It seems that the lack of support from senior management could impact on the quality of financial reporting through a tolerance of poor accounting practice. Respondent 10 made the following remark at the start of the interview:

'The main problem I have encountered as a consultant is that there is little, if any, management buy-in. In other words, management does not view IFRS as a priority, sees little benefit in devoting resources to it and it has only decided to produce IFRS financial statements to fulfill a regulatory obligation.'

Respondent 1 began his interview by stating:

'The biggest problem is the cultural challenge. Typically there is a big resistance to change and the question that is asked first is "do we have to do this". To get round this problem there should be a board member and the finance director at the initial meeting where IFRS adoption is discussed. Otherwise it just becomes "an accounting problem" and unless there is lead from the top it is hard to get people to take it seriously, devote resources etc. It is key to have sponsorship at board level - but this is usually lacking. There needs to be a dynamic 
individual in charge of the project who can "sell" the transition and encourage the accountants and others in the business to embrace the changes rather than fight against them.'

For many public sector reporting entities, the move to IFRS is much more of a shift in the financial reporting framework than for private sector firms. A respondent who was heavily involved with the transition of public sector entities to IFRS spoke of a lack of acceptance of the process at senior executive level. This attitude permeated the whole organisation, meaning that the transition project was viewed negatively by almost everyone involved. There were no IFRS 'champions' who would sell the benefits, or even explain the reasons for the changes to the staff involved. The accounting personnel simply saw the transition as a huge and unnecessary change that brought about extra work, tighter deadlines, the need for re-education and could possibly threaten people's jobs. It was very difficult to embed IFRS reporting in an organisation where there was an all-encompassing reluctance to accept the changes that has persisted post transition.

The respondents make a link between the lack of management buy-in to the transition project and the issue of resourcing the project. It would seem that where management sees the transition as 'just an accounting issue' rather than a matter affecting several areas of the business, and are generally unwilling to support the project, there are insufficient resources allocated, leading to overworked accountants attempting to complete the transition in addition to their day-to-day responsibilities. Respondent 8 commented that 'the staff involved in finance still had to complete their normal duties, so the transition to IFRS presents additional work over and above the normal workload'.

This situation has important implications for the quality of financial information generated, and can cause delays and inefficiencies when errors later have to be corrected or "patch ups" applied to minimise the errors.

A further implication of a lack of support from senior management relates to the fact that accounting under IFRS requires the preparer of the financial statements to engage with dialogue with other business functions to obtain the information necessary to determine accounting treatments. A typical example is that the accountant may rely on information supplied by the treasury management function in order to determine the accounting treatment for financial instruments such as derivatives. Similarly, the human resources department may need to provide information relating to employee benefits, such as holiday entitlement which results in the recognition of an accrual. Where management does not acknowledge the importance to the transition process of inputs from across the reporting entity's operations, the accountant may find it difficult to elicit the necessary information and support across the business. This links to the final two challenges of transition that will be discussed later in this section.

Lantto (2014, p.349) describes IFRS as emphasising the 'the importance of business involvement (or close connection with business) in accounting'. Lantto suggests that the accountants act as 'brokers', connecting the accounting function and the various business 
divisions and helping to transfer knowledge on IFRS, ultimately 'transferring the events and transactions of the divisions into reporting practice'. Without the backing of senior management it is hard to envisage how the accountant could act as a 'broker', as there would be little support for the accountant to engage successfully with people from other business divisions. The comments of several interviewees support this, suggesting that when management did not explain the importance of the IFRS transition to the business as a whole, it was seen as 'just an accounting problem' and members of other business functions were reluctant to become involved or supply information when requested. This is a major implementation challenge, especially when transition projects are typically conducted to a short deadline.

\subsection{Underestimating the wider implications of the transition to IFRS for the business}

One possible explanation for the apparent lack of support for the IFRS transition in many reporting entities is the fact that at the planning stage, few people within the reporting entity could foresee the wider business implications of the transition. With the benefit of hindsight, more support could have been given to the accountant, and this is a useful lesson for those still planning their transition and for regulatory bodies wishing to formulate guidance to help those preparing to adopt IFRS. The wider implications include financial effects such as the impact on accounting ratios, debt covenants, treasury management policy and the level of dividend and bonus payments. There may also be a need to renegotiate contracts, clarify the wording of agreements, improve documentation, and amend financial and operational systems and controls. It can be argued that if management were presented with an indication of the wider implications when IFRS implementation is first being planned, there would be more interest and support at the executive level. Respondent 5 gave the following example of an unforeseen implication of adopting IFRS:

'To give an example of an unexpected wider impact, this happened with a company that had an old deferred revenue balance which could no longer be deferred under IAS 18 Revenue. If the revenue were recognised there would be tax due, which would have resulted in a big cash outflow. The IFRS transition for this company was not mandatory, and it was actually cancelled to avoid the cash outflow.'

Respondent 12 described a useful illustrative example of widespread impact for a systems manufacturer operating in the aerospace industry. The company supplied systems and components to a number of customers, each of which was a significant source of revenue for the company. Typically a customer approaches the company to design, develop and install major aircraft systems such as electrical, safety and mechanical systems. Each contract to supply is designed to include milestones, and for each project a Gantt Chart is developed which influences the timing of invoices being raised. Project managers are assessed on how and when milestones are reached, and a system may take several years from the initial concept and enquiry to successful project completion.

Revenue recognition is a significant issue in this scenario. The existence of milestones can trigger the recognition of revenue. On adopting IAS 18 Revenue, the company decided to 
amend the contract milestones which thereby changing the pattern of revenue recognition in the financial statements. This had significant business implications for the project managers and engineers working on the systems being developed. The project managers were frustrated at the changes to an ongoing contract and the consequential impact on project cash flows altered the project's Net Present Value calculations. The resulting confusion as to why the changes were made meant the company had to spend time explaining the issues to the engineers and project managers, and there was an impact on staff morale.

A further issue arose in relation to research and development. Under previous GAAP there was no requirement to capitalise development costs, so the company did not have systems and processes in place to separate research costs from development costs. On transition to IFRS, IAS 38 Intangible Assets requires development costs to be assessed in order to determine if they need to be capitalised as an intangible asset. The obvious implication was that the company had to spend time to develop a system of categorising research and development spending including a very clear policy on how to differentiate the two, and also develop methods of assessing whether development costs met the IAS 38 criteria for capitalisation. In many instances there is a grey area between what is research and what is development and management, not being used to exercising judgement in this area, found this problematical. A complicating factor existed in that the project managers wanted the engineers working on their projects to capitalise as much cost as possible, as this could then be charged to the customer. There was therefore pressure and incentive for research costs to be treated as development costs, especially at the point in time when the contract activity was on the cusp of turning from feasibility studies and research to more applied development activity. For this company, none of these issues were really considered in detail until late in the transition project. The company, with the benefit of hindsight, would have planned for the non-accounting issues earlier and in a more robust manner, taking time to discuss the implications of changing systems with project managers and engineers, and potentially avoiding some of the conflicts and morale problems that occurred.

This illustration highlights the significance of the wider implications of adopting new financial reporting requirements. Wider implications were stated as challenges by most of the interviewees, with the most commonly cited implications being related to communication difficulties between business divisions, impacts on debt covenants and other key measures and negative impacts on staff morale. This is an under-researched area, and would benefit from further exploration, especially given that fear of the wider-implications of adopting IFRS may deter companies from moving to adopt IFRS.

\subsection{Problems in data-capture and obtaining the necessary information for disclosure}

Several respondents stressed that many of the transitions to IFRS they had oversaw were made very difficult due to the problems of obtaining the information necessary to prepare the first IFRS-compliant financial statements. The reasons are varied, link back to the previously discussed findings, and include the lack of knowledge of IFRS (especially regarding disclosure requirements), insufficient time and resources to adequately plan for the 
transition, and cultural issues in certain sectors meaning that undermine the rigour of relevant documentation. Respondent 4 commented as follows:

'It is difficult to get some information that is needed under IFRS, where that information was not needed under previous GAAP. For example, the company's bank may need to provide the fair value of financial instruments. The company hasn't got the knowledge to do it, and the information can be difficult to get in retrospect. One example is in relation to swaps, there was a lack of documentation at the client and the valuation work was very time consuming. Careful planning is needed to ensure that information can be made available, but this is difficult if you don't have a good knowledge of IFRS disclosure requirements.'

Respondent 1 suggested that the lack of documentation at certain public sector entities was a major impediment to a successful transition to IFRS:

'There are major challenges in relation to retained knowledge and documentation. In the public sector there is often a lack of evidence and people "just know" how things work. For example, there may not be a contract register, out-of-date lease agreements are on file, generally there is a lack of paper trail. There may not be any succession planning, so only one person knows about an issue, and when they leave that knowledge is lost. This needs to be resolved and a better "corporate memory" and system for information retention established.'

Respondent 8 reaffirms these ideas:

'Some of the issues encountered in an IFRS transition require access to information that is historic and not necessarily available in a finance department. Examples include major contracts, leasing agreements, details on asset componentisation and staff holidays for working out short-term accumulated absences accruals. I have seen finance staff spent significant time tracking down documentation in order to make reliable assessments on significant areas. It brought to light the need for those finance departments to engage with the wider oragnisation both in terms of accessing the information going forward and advising non-finance personnel of the implications of decisions and transactions they are considering under the organisation's new IFRS-based accounting policies.'

It is interesting to note that several respondents stressed this issue as one of the most frustrating in IFRS implementation projects. The lack of information and documentation does not mean that IFRS cannot be successfully implemented, but it causes significant inefficiencies and diverts scarce resources to paper-chasing and information gathering.

We conclude our section of findings by comparing our results with those challenges listed by Jermakowicz and Gornik-Tomaszewski (2006) referred to in Table 1. A direct comparison is not possible due to a different classification of implementation challenges and because their study focused on accounting issues rather than organisational responses to IFRS implementation. However some interesting points of comparison can be made. The 2006 study examined the EU implementation of IFRS and the challenges it identifies highlight the lack of experience with IFRS and the need for training. Lack of knowledge and 
understanding was similarly the biggest challenge raised by our respondents, even by those located in Canada, where the IFRS transition lagged that in the EU by several years. It would appear that IFRS knowledge and experience is not acquired until necessary, with Canadian auditors and preparers of financial statements not becoming familiar with IFRS requirements until they needed to apply it themselves for the first time. This in itself is an area suitable for further research, as our sample of non-EU respondents is too small to reach further conclusions on cross-country analysis.

Our findings also suggest other significant challenges that were not identified either in the previous study or in other research. Our respondents raised issues relating to the lack of management support, failure to anticipate the wider implications for the business of the transition, and over reliance on experts. All of these issues are relevant to organisations planning to move to IFRS-based reporting in the future. Our findings would seem to open up a black box of challenges that extend beyond technical accounting issues into a wider organisational context. The findings suggest that when planning to respond to changes in IFRS requirements, organisations need to carefully plan how to engage with external experts, how to secure executive support for the transition and how to engage with business functions other than the accounting division.

We also suggest that the issue of auditor objectivity when providing guidance and advice to an audit client can create threats to objectivity, with implications for the credibility of financial statements. Additionally, over reliance on help from auditors or consultants limits the amount by which knowledge and skills become embedded within the entity, leading to on-going problems when preparing subsequent financial statements and especially when existing IFRS requirements are revised or new ones introduced.

\section{Conclusion}

The objective of this paper is to study the challenges to implementation of IFRS at an organisational level, as perceived by experts providing advice and guidance to the preparers of financial statements. Our literature review found that while there is a significant volume of quantitative research on the financial effects of IFRS implementation, the actual process of adoption of IFRS by reporting entities is not widely researched. We employed qualitative research methods to explore the opinions of a group of professionals with experience in many jurisdictions and with 170 individual transitions.

We find that the major challenges identified in our interviews highlight the fact that the organisations were under prepared for the transition to IFRS. This was often due to lack of education and training, and because the transition was considered to be 'the accountant's problem', with the wider implications for the business not anticipated. Surprisingly, very few of the respondents identified the complexity of specific IFRS requirements as a challenge, other than with regard for the need for education and training on IFRS requirements. Where IFRS requirements were specifically referenced, the implementation challenge tended to be linked to the use of judgment rather than the application of a complex rule. Successful IFRS implementations are those that start early, are planned using project management techniques, 
provide training at the outset to the relevant staff, secure executive level sponsorship of the project, and identify and respond to the wider business implications of the transition.

We suggest that for reporting entities that are yet to adopt IFRS, the challenges may prove to be less significant, as comprehensive IFRS training is now readily available, and many more accountants are IFRS-literate. However, in jurisdictions where previous accounting requirements were rule-based, the adoption of more principle-based IFRS may continue to pose challenges.

As discussed earlier, most jurisdictions have already moved towards IFRS, at least for their publically accountable reporting entities. We therefore acknowledge that the lessons to be learnt from the findings of this paper are limited, as so many reporting entities have already gone through transition. Those reporting entities yet to adopt IFRS will have less of a challenge in finding accountants with the required knowledge and experience of IFRS. Additionally, where the move to IFRS is voluntary rather than mandatory, there is likely to be more support within the organisation for the implementation, alleviating many of the transition challenges reported by our interviewees.

Nonetheless, the business wide challenges relating to systems, knowledge sharing and executive support may remain. Consequently, we feel that the findings are relevant to future transitions in several contexts. First, in some jurisdictions, such as the UK where national financial reporting standards are becoming more aligned with IFRS, so organisations using the national financial reporting standards will need to implement new IFRS based accounting policies, albeit as amended for local adoption. This is a mandatory change and therefore may face the same resistance as seen in other mandatory adoption scenarios.

In the small number of jurisdictions yet to adopt IFRS, such as Vietnam, similar challenges to those outlined by our findings are still likely to be faced. For example, while there may be more expertise globally in IFRS, in countries such as Vietnam there are very few professionally qualified accountants with expertise and experience in applying IFRS (this observation is based on the authors' personal experiences in Vietnam). Additional challenges will also be present, for example language barriers making the translation and interpretation of IFRS requirements difficult, and cultural factors including a historically prescriptive accounting regime will pose different challenges.

In addition, in jurisdictions already adopting IFRS for some reporting entities, there are potential implementation challenges when IFRS are applied in a different context. In the UK, for example, where public sector adoption of IFRS lagged that of the private sector by several years, our findings show that despite being in the same jurisdiction, similar challenges were faced several years on from the private sector transition. The implication is that, despite the benefit of hindsight, lessons were not transferred across sectors. Similar problems may occur in other jurisdictions.

Possibly more significantly, IFRS is a moving target, with new and revised IFRS requirements being published regularly. This means that for organisations that have already adopted IFRS, the introduction of a significant new or revised standard will present 
implementation challenges. The organisation will have gone through the implementation learning curve on its initial adoption of IFRS, but there may still be important planning issues to consider when implementing a new standard such as IFRS 9 Financial Instruments and IFRS 15 Revenue from Contracts with Customers. These may include a need for training, planning to ensure that sufficient data is captured, and consideration of the wider business implications. The IASB's plans to introduce a new financial reporting standard on lease accounting before the end of 2015 (IFRS Foundation, 2015) is likely to have a significant impact on many reporting entities and such planning will be extremely important for the organisations affected.

We suggest that further qualitative studies at the organisational level would add to the literature on IFRS transition. Acknowledging the limited geographical spread of our study, there are research opportunities focusing on jurisdictions that have more recently moved to implement IFRS either by full adoption of IFRS or through convergence of their national financial reporting standards. It would be interesting to compare the current challenges faced by those organisations implementing IFRS now to those experienced in the past. In addition we note that the issue of IFRS implementation and its links to auditor independence is underresearched and one with potential implications for both audit quality and audit regulation. We also suggest that research specific to IFRS-implementation in the public sector would add to the literature by providing an interesting contrast of the challenges faced in adopting IFRS in the private versus public sectors.

The findings of this paper indicate that preparers of financial statements would benefit from IFRS implementation guidance. Whilst this guidance can be provided by external consultants and audit firms, it may be appropriate for policy makers to consider the need to provide generic support. Providing implementation support may not only help the reporting entities that involved in the transition to IFRS, but could help to improve the quality of financial information by reducing the scope for errors and mis-judgments in the application of IFRS. In its response to the European Commission's 2014 consultation on IFRS adoption in the EU (European Commission, 2014), the IFRS Foundation comments that whilst reports issued by the European Securities and Markets Authority (ESMA) suggest that the implementation of IFRS is considered to have improved the quality of financial information, there is still room for improvement in certain areas (IFRS Foundation, 2014b).

To conclude, it seems that while there is an extensive and varied pool of research on the use of IFRS, there is little qualitative research examining the planning and execution of implementation at an organisational level. There is room for more exploration of this topic including the extent to which transitioning entities rely on external help, and the common challenges that are faced by those advising on and involved in the transition. Whilst our paper takes a historical perspective, the issues discussed are still pertinent today. Future research might consider the challenges faced by organisations who voluntarily move to adopt IFRS, entities in jurisdictions which are converging national financial reporting standards with IFRS, or by reporting entities already using IFRS but faced with the implementation of new or substantially revised IFRS requirements. There remains much to be learned in the field. 


\section{Bibliography}

Aisbitt, S. (2006). Assessing the Effect of the Transition to IFRS on Equity: The Case of the FTSE 100. European Accounting Review, 15, 117-133.

Aubert, F., \& Grudnitski, G. (2012). Analysts' estimates: What they could be telling us about the impact of IFRS on earnings manipulation in Europe. Review of Accounting and Finance, 11(1), 53-72. doi: 10.1108/14757701211201821

Bennett, B., Bradbury, M., \& Prangnell, H. (2006). Rules, principles and judgments in accounting standards. Abacus, 42(2), 189-204. doi: 10.1111/j.1467-6281.2006.00197.x

Carmona, S., \& Trombetta, M. (2008). On the global acceptance of IAS/IFRS accounting standards: The logic and implications of the principles-based system. Journal of Accounting and Public Policy, 27, 455-461. doi: 10.1016/j.jaccpubpol.2008.09.003

CESR. (2003). European Regulation On The Application Of IFRS In 2005 - Recommendation For Additional Guidance Regarding The Transition To IFRS December 2003. Paris: CESR.

CFERF. (2013). The Cost of IFRS Transition in Canada. Toronto: Candian Financial Executives Research Foundation.

Cordazzo, M. (2013). The impact of IFRS on net income and equity: evidence from Italian listed companies. Journal of Applied Accounting Research, 14(1), 54-73. doi: http://dx.doi.org/10.1108/09675421311282540

Daske, H. (2006). Economic benefits of adopting IFRS or US-GAAP - Have the expected cost of equity capital really decreased. Journal of Business Finance and Accounting, 33(3-4), 329-373. doi: 10.1111/j.1468-5957.2006.00611.x

De George, E. T., Ferguson, C. L., \& Spear, N. A. (2013). How Much Does IFRS Cost? IFRS Adoption and Audit Fees. The accounting review, 88(2), 429.

Deakin, H., \& Wakefield, K. (2014). Skype interviewing: reflections of two PhD researchers. Qualitative Research, 14(5), 603-616. doi: 10.1177/1468794113488126

Deloitte. (2009). Strategic choices on the conversion to IFRS. Beyond Complance. Retrieved 5 January 2014, from http://www.deloitte.com/assets/DcomCanada/Local\%20Assets/Documents/ca_en_IFRS_Volllbooklet_Mar09.pdf

DiMaggio, P. J., \& Powell, W. W. (1983). The Iron Cage Revisited: Institutional Isomorphism and Collective Rationality in Organizational Fields. American Sociological Association(2), 147.

Etnyre, V., \& Singhal, P. (2011). The Effect Of New International Accounting Standards On Firms From India and the US. Academy of Accounting \& Financial Studies Journal, 15(3), 147-154.

European Commission. (2014). Effects of using International Financial Reporting Standards (IFRS) in the EU: public consultation.

Filip, A., \& Raffournier, B. (2013). The value relevance of earnings in Europe after IFRS implementation: Why do national differences persist? International Journal of Accounting, Auditing and Performance Evaluation, 9(4), 388-415. doi: 10.1504/IJAAPE.2013.057527

Financial Reporting Council. (2014). FRS 100 Application of Financial Reporting Requirements. Retrieved 30 September 2014, from https://www.frc.org.uk/OurWork/Publications/Accounting-and-Reporting-Policy/FRS-100-Application-of-FinancialReporting-Require.pdf

Grant Thornton. (2012). The road to IFRS - a practical guide to IFRS 1 and first time adoption. Retrieved 20 December 2013, from http://www.grant.thornton.no/files/theroadtoifrs.pdf

Hail, L., Leuz, C., \& Wysocki, P. (2010). Global Accounting Convergence and the Potential Adoption of IFRS by the U.S. (Part I): Conceptual Underpinnings and Economic Analysis. Accounting Horizons, 24(3), 355-394. doi: 10.2308/acch.2010.24.3.355 
Hoogendoorn, M. (2006). International Accounting Regulation and IFRS Implementation in Europe and Beyond -- Experiences with First-time Adoption in Europe. Accounting in Europe, 3, 23 26.

Hoogervorst, H. (2013). Are we there yet? Charting the world's progress towards global accounting standards - A Speech at the IFRS Asia-Oceania Policy Forum, June 2013.

ICAEW. (2014a). The Effects of Mandatory IFRS Adoption in the EU: A Review of Empirical Research. London: ICAEW.

ICAEW. (2014b). EU IFRS adoption was beneficial. Retrieved 10 June 2015, from http://economia.icaew.com/news/november-2014/eu-ifrs-adoption-wasbeneficial\#sthash.XWR7uej8.dpuf

ICAS. (2008). The Implementation of IFRS in the UK, Italy and Ireland. Edinburgh: ICAS.

IESBA. (2015). Code of Ethics for Professional Accountants 290.4.

IFRS Foundation. (2010). Conceptual Framework for Financial Reporting. Retrieved 20 June 2014, from http://eifrs.ifrs.org/eifrs/bnstandards/en/2014/conceptual_framework_unaccompanied.pdf

IFRS Foundation. (2014a). About the IFRS Foundation and the IASB. Retrieved 13 September 2014, from http://www.ifrs.org/About-us/Pages/IFRS-Foundation-and-IASB.aspx

IFRS Foundation. (2014b). European Commission Evaluation Of The International Accounting Standards (IAS) Regulation: A Perspective From The Staff Of The IFRS Foundation. Retrieved 24 November 2014, from http://www.ifrs.org/Alerts/Governance/Documents/2014/IFRSFoundation-staff-perspective-EC-consultation-September-2014.pdf

IFRS Foundation. (2015). Work Plan for IFRSs: Leases. Retrieved 2 June 2015, from http://www.ifrs.org/Current-Projects/IASB-Projects/Leases/Pages/Leases.aspx

Ionaşcu, I., Ionaşcu, M., Olimid, L., \& Calu, D. A. (2007). An Empirical Evaluation of the Costs of Harmonizing Romanian Accounting with International Regulations (EU Directives and IAS/IFRS). Accounting in Europe, 4(2), 169-206. doi: 10.1080/17449480701727965

Jermakowicz, E. K., \& Gornik-Tomaszewski, S. (2006). Implementing IFRS from the perspective of EU publicly traded companies. Journal of International Accounting Auditing \& Taxation, 15(2), 170.

Kim, J.B., Shi, H., \& Zhou, J. (2014). International Financial Reporting Standards, institutional infrastructures, and implied cost of equity capital around the world. Review of Quantitative Finance and Accounting, 42(3), 469-507. doi: http://dx.doi.org/10.1007/s11156-013-0350-3

Kim, J. B., Liu, X., \& Zheng, L. (2012). The impact of mandatory IFRS adoption on audit fees: Theory and evidence. Accounting Review, 87(6), 2061-2094. doi: 10.2308/accr-50223

KPMG. (2009). Disclosing the Impact of Adopting IFRS - When and How? Retrieved 10 January 2014, from

http://www.kpmg.com/Ca/en/IssuesAndInsights/ArticlesPublications/Documents/3174_Disc losing_reprint_Web.pdf

Lantto, A.-M. (2014). Business Involvement in Accounting: A Case Study of International Financial Reporting Standards Adoption and the Work of Accountants. European Accounting Review, 23, 335-356. doi: 10.1080/09638180.2013.833411

Legard, R., Keegan, J., \& Ward, K. (2003). In-depth interviews. In J. Ritchie \& J. Lewis (Eds.), Qualitative Research Practice - A Guide for Social Science Students and Researchers (pp. 138 169). London: Sage Publications.

Naoum, V.-C., Sykianakis, N., \& Tzovas, C. (2011). The perceptions of managers of Greek firms regarding the Costs and Benefits ensuing from the adoption of International Financial Reporting Standards in Greece. International Journal of Economic Sciences \& Applied Research, 4(3), 59-74.

Pactor, P. (2014). Global Standards: How Close Are We? Speech at the 2014 MIT Asia Conference, July 2014. Retrieved 30 September 2014, from http://www.ifrs.org/Use-around-theworld/Documents/Global-standards-how-close-are-we-July-2014.pdf 
Pactor, P. (2015). Financial Reporting Standards for the World Economy. Retrieved 10 June 2015, from http://www.ifrs.org/Use-around-the-world/Documents/Financial-Reporting-StandardsWorld-Economy-June-2015.pdf

PwC. (2007). Presentation of income under IFRS: flexibility and consistency explored. Retrieved 11 January 2014, from http://www.pwc.com/en_GX/gx/ifrsreporting/pdf/europesurveynongaapmeasures.pdf

PwC. (2009). Preparing your first IFRS financial statements. Retrieved 22 January 2014, from http://www.pwc.com/us/en/issues/ifrs-reporting/publications/preparing-first-ifrs-financialstatements.jhtml

Redmayne, N. B., \& Laswad, F. (2013). An Assessment of the Impact of IFRS Adoption on Public Sector Audit Fees and Audit Effort - Some Evidence of the Transition Costs on Changes in Reporting Regimes. Australian Accounting Review, 23(1), 88-99. doi: 10.1111/j.18352561.2012.00166.x

Schofield, J. W. (2002). Increasing the Generalizability of Qualitative Research. In A. M. Huberman \& M. B. Miles (Eds.), The Qualitative Researcher's Companion. London: Sage Publications.

SEC. (2007). Concept Release On Allowing U.S. Issuers To Prepare Financial Statements In Accordance With International Financial Reporting Standards. Washington: SEC.

Shuy, R. W. (2002). In-Person Versus Telephone Interviewing. In J. F. Gubrium \& J. A. Holstein (Eds.), Handbook of Interview Research - Context and Method (pp. 537 - 555). London: Sage Publications.

Stoner, G., \& Holland, J. (2004). Using Case Studies in Finance Research. In C. Humphrey \& B. Lee (Eds.), The real life guide to accounting research : a behind-the-scenes view of using qualitative research methods (pp. 37 - 56): Amsterdam ; London : Elsevier, 2004.

Sucher, P., \& Jindrichovska, I. (2004). Implementing IFRS: A Case Study of the Czech Republic. Accounting in Europe, 1, 134.

Touron, P. (2005). The adoption of US GAAP by French firms before the creation of the International Accounting Standard Committee: An institutional explanation. Critical Perspectives on Accounting, 16(6), 851-873. doi: 10.1016/j.cpa.2003.08.011

Tsoligkas, F., \& Tsalavoutas, I. (2011). Value relevance of R\&D in the UK after IFRS mandatory implementation. Applied Financial Economics, 21(13), 957.

Walton, P. (2009). An Executive's Guide for Moving from US GAAP to IFRS. New York: Business Expert Press.

Welch, C., Marschan-Piekkari, R., Penttinen, H., \& Tahvanainen, M. (2002). Corporate elites as informants in qualitative international business research. International Business Review, 11, 611-628. doi: 10.1016/S0969-5931(02)00039-2

Wüstemann, J., \& Wüstemann, S. (2010). Why Consistency of Accounting Standards Matters: A Contribution to the Rules-Versus-Principles Debate in Financial Reporting. Abacus, 46(1), 1 27. doi: 10.1111/j.1467-6281.2010.00304.x

Zeff, S. A. (2012). The Evolution of the IASC into the IASB, and the Challenges it Faces. Accounting Review, 87(3), 807-837. doi: 10.2308/accr-10246 
Appendix 1: Details of The Respondents

\begin{tabular}{|l|l|l|l|l|l|}
\hline Respondent & $\begin{array}{l}\text { Country in } \\
\text { which } \\
\text { respondent } \\
\text { is located }\end{array}$ & $\begin{array}{l}\text { Nature of involvement } \\
\text { with IFRS } \\
\text { implementation }\end{array}$ & $\begin{array}{l}\text { Public } \\
\text { or } \\
\text { private } \\
\text { sector } \\
\text { focus }\end{array}$ & $\begin{array}{l}\text { Approximate } \\
\text { number of } \\
\text { IFRS } \\
\text { transitions } \\
\text { involved with }\end{array}$ & $\begin{array}{l}\text { Dates of } \\
\text { involvement } \\
\text { with IFRS } \\
\text { transition }\end{array}$ \\
\hline R1 & UK & Auditor - mid-tier firm & Public & 20 & $\begin{array}{l}2008- \\
\text { present time }\end{array}$ \\
\hline R2 & $\begin{array}{l}\text { Republic of } \\
\text { Ireland }\end{array}$ & Auditor - mid-tier firm & Private & 9 & $\begin{array}{l}2005- \\
\text { present time }\end{array}$ \\
\hline R3 & UK & Auditor - mid-tier firm & Private & 4 & $2005-2011$ \\
\hline R4 & UK & Auditor - "Big 4" firm & Private & 5 & $2005-2007$ \\
\hline R5 & $\begin{array}{l}\text { Republic of } \\
\text { Ireland }\end{array}$ & Auditor - "Big 4" firm & Private & 16 & $\begin{array}{l}2005- \\
\text { present time }\end{array}$ \\
\hline R6 & Canada & Consultant & Private & 5 & $2010-2013$ \\
\hline R7 & Canada & Consultant & Private & 20 & $2009-2014$ \\
\hline R8 & UK & Consultant & Public & 8 & $2008-2012$ \\
\hline R9 & Australia & Consultant & Public & 8 & $2005-2006$ \\
\hline R10 & $\begin{array}{l}\text { Czech } \\
\text { Republic }\end{array}$ & Consultant & Private & 7 & $\begin{array}{l}2006- \\
\text { present time }\end{array}$ \\
\hline R11 & Germany & Consultant & Private & 15 & $\begin{array}{l}2005- \\
\text { present time }\end{array}$ \\
\hline R12 & Canada & Consultant & Private & 50 & $2008-2013$ \\
\hline R13 & $\begin{array}{l}\text { Republic of } \\
\text { Ireland }\end{array}$ & Consultant & Private & 10 & $\begin{array}{l}2005- \\
\text { present time }\end{array}$ \\
\hline R14 & UK & Auditor - mid-tier firm & & 5 & $2005-2008$ \\
\hline & & & 170 & \\
\hline
\end{tabular}




\section{Appendix 2: Examples of questions used in interviews and thought-provokers sent to respondents for written responses}

Can you describe your involvement with IFRS implementation?

Can you explain the challenges that you encountered during your involvement with IFRS implementation at your clients?

Can you expand on challenges faced by the client (rather than yourself)?

Can you prioritise these challenges and explain your reasoning?

With the benefit of hindsight, how might IFRS implementations been better planned?

Can you provide examples of wider impacts of the transition for your clients i.e. impacts seen outside of the accounting function?

Were there often last-minute issues or problems and why did they arise? 